\title{
Eating approach of bereaved individuals: A protocol proposal
}

\author{
Abordagem alimentar de enlutados: \\ uma proposta de protocolo
}

\author{
Maria Teresa Fialho de Sousa CAMPOS1 (iD 0000-0002-5429-1312 \\ Maria do Carmo Gouveia PELUZIO ${ }^{1}$ iD 0000-0003-4665-7043 \\ Raquel Maria Amaral ARAÚJO1 (D) 0000-0003-1323-8707
}

A B S T R A C T

\section{Objective}

The objective of this manuscript was to discuss the care inherent to the methodological procedures for food research in bereavement situations, proposing the use of a conduct protocol.

\section{Methods}

The protocol for food research in bereavement is presented, based on the critical review of literature and the experience with food surveys applied to bereaved people.

\section{Results}

The conduct protocol is divided into three moments corresponding to the meetings and the steps of approach are discussed in these care services. This research seeks to problematize this investigation, outlining the phases of coping with bereavement that involve greater adherence, from these individuals, to food surveys.

\section{Conclusion}

The conduct protocol guiding the investigation of eating habits of bereaved individuals provides information that allows the professional to evaluate the influence of bereavement on food in addition to allowing a greater adherence of these individuals to the survey.

Keywords: Bereavement. Diet survey. Protocols.

\footnotetext{
${ }^{1}$ Universidade Federal de Viçosa, Departamento de Nutrição e Saúde, Programa de Pós-Graduação em Ciência da Nutrição. Campus Viçosa, Av. P.H. Rolfs, s/n., 36570-000, Viçosa, MG, Brasil. Correspondência para/Correspondence to: MTFS CAMPOS. E-mail: <mtcampos@ufv.br>.

Article based on the doctoral thesis of MTFS CAMPOS, entitled "Comportamento alimentar de mães com vivência em perda de filho(a)". Universidade Federal de Viçosa; 2018.
}

\footnotetext{
Como citar este artigo/How to cite this article

Campos MTFS, Peluzio MCG, Araújo RMA. Eating approach of bereaved individuals: A protocol proposal. Rev Nutr. 2018;31(3):325-37. http://dx.doi.org/10.1590/1678-98652018000300006
} 


\section{R E S U M O}

\section{Objetivo}

O objetivo deste manuscrito é discutir os cuidados inerentes aos procedimentos metodológicos para pesquisa em alimentos em situações de luto, propondo o uso de um protocolo de conduta.

\section{Métodos}

Apresenta-se o protocolo para a investigação alimentar em situações de luto, desenvolvido com base na revisão crítica da literatura e na vivência com inquéritos alimentares aplicados a enlutados.

\section{Resultados}

O protocolo de conduta é dividido em três momentos, correspondentes aos encontros nos quais se discutem as etapas de abordagem. Busca-se problematizar essa investigação, delineando as fases de enfrentamento do luto que comportam maior adesão dos enlutados aos inquéritos alimentares.

\section{Conclusão}

O estudo conclui que o protocolo de condutas para conduzir a investigação alimentar de enlutados fornece informações que permitem ao profissional avaliar a influência do luto na alimentação, bem como atende à maior aderência desses indivíduos ao inquérito.

Palavras-chave: Luto. Inquérito alimentar. Protocolos.

\section{NTROD UCTION}

The dietary approach of individuals requires personal skills from the interviewer so that the information regarding food consumption and eating behavior portrays the real thing as accurately as possible. Much of what will be done in an intervention or even in scientific research depends on the approach taken $[1,2]$ at that time. The interviewer depends on the predisposition of his or her interlocutor or the strategies to motivate this individual, oriented to the promotion of the conditions of empathy [3] and confidence conducive to a dense narrative [4] by the interviewee. These conditions become more challenging in situations where the interlocutor is under high emotional stress, as in cases of bereavement.

Facing the loss of a beloved one and the suppression of living with this person, people may be affected in their way of being $[5,6]$. The death of a beloved one, depending on the established affective bond, the emotional regulation profile and the individual coping mechanism, triggers a series of reactions in the fields of emotion and reasoning [7]. This situation results in changes in mood and behavior patterns, affecting the bereaved individuals' relationship to food and, consequently, altering food consumption [7]. Under these conditions, conducing food surveys brings special challenges other than those inherent in research methods and techniques [2,8-10].

Human diet, as it involves psychological, physiological, endocrine, sociocultural and behavioral aspects, becomes a phenomenon of great complexity [11-14], requiring, for its investigation, the use of detailed and extensive survey forms [9], which are not applicable to bereaved ones. It becomes necessary to provide an instrument that integrates the experience of bereavement into eating habits and that guides the approach to obtaining quality information, respecting the affective-emotional condition of the bereaved, as a result of the impact of such event regarding their quality of life and nutritional conditions.

Among the theoretical and technical challenges involved in a decision to choose methods and forms of food research that are more applicable to bereaved individuals, there is also an in-depth knowledge of the different modes of approach [15-18]. The investment in collection instruments that contextualize bereavement related to eating, through adequate 
protocols, should enable quality information centered on the perception of the bereaved, insofar as it encompasses feelings, conceptions and intentions that are more prevalent in the act of ingestion. The literature has presented an increasing scientific production related to bereavement [19], pointing out concern about the condition of life and health of these people. In the area of nutrition, special attention is required in bereavement, through the deepening of the thematic, with appropriate approaches and analyzes based on the perspective of narratives and phenomenology. Thus, the objective of this manuscript was to address the care inherent in methodological procedures that apply to eating habits under the influence of bereavement, proposing a conduct protocol that can serve both research and professional care.

\section{METHODS}

The proposal of the food survey protocol for the bereaved was based on a critical review, based on specific literature and experiences of the researcher on this subject, working with groups attending NGO meetings of Bereavement Support groups and researching the eating behavior of bereaving mothers (CAAE 45311215.0.0000.5153).

A search was made for scientific manuscripts that dealt with the themes "Eating Attitudes"; "Eating Behavior"; "Eating Inquiries"; "Bereavement" and "Traumatic Stress". In order to access this collection, the following descriptors were searched: in the Coordenação de Aperfeiçoamento de Pessoal de Nível Superior (CAPES, Coordination for Higher Education Staff Development) journal and in the Science Direct and SciELO databases, "Feeding behavior"; "Eating habits"; "Food surveys"; "Death" and "Stress"; "Mourning"; "Bereavement"; "Grief"; "Traumatic event"; "Traumatic stress". Publications that did not fit the theme of interest were excluded from the theoretical framework. Nutrition books that address validated methodological procedures for consumption and food behavior studies also compiled the collection of this review. Literature referring to the methodology of qualitative research was also consulted, since it guides and provides the researcher with the proper tools to approach subjective aspects of human behavior.

The chosen route for the construction of the instrument was based on the information obtained in the literature regarding the emotional vulnerability of bereaved individuals, including the condition of post-traumatic stress disorder and state of melancholy and/or distress due to the death of the beloved one, stages of reactions to bereavement and the pattern of personality that made up the theoretical assumptions to substantiate the choices of method and protocol. From the options of dietary inquiries $[2,8,20]$ and behavioral feeding $[9,14,21]$, methodological procedures and approaches were set to determine the dietary inquiries regarding bereaved individuals. The laying out of this protocol and its subsequent improvement resulted from a pre-testing with eating surveys applied to bereaved individuals and from observations pointed out by this group to the researchers.

\section{RESULTS AND DISCUSSION}

The dietary approach protocol is presented (Figure 1), which is divided into three moments corresponding to the meetings, and discusses the steps of approach, seeking to problematize the decisions that substantiated this proposal.

The purpose of this protocol is based on obtaining information essential and intrinsic to the bereavement (characterization of the death, the bereavement and the dimension of pain), adding them to the eating habit surveys demarcated by the interviews. The difficulty in dealing with the death of a beloved one favors the vulnerability to distress [7], for this reason, it 
is proposed a more succinct protocol of eating habits collection. Each individual is unique in the cognitive process to process emotions and feelings, which is called: emotional regulation profile [22]. Conceiving that this profile of emotional regulation interferes with the individual's ability to cope with stress $[23,24]$, there are discrepancies and differences in dealing with the death of the beloved one and their reaction to the surveys.

\section{1st Appointment}

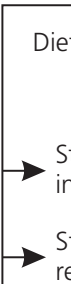

Dietary habits interview

$\longrightarrow$ non-directive

(Figure 2)

Study about the bereaved

individual's food perception

Study of the influence of affective

relations on eating attitudes

\section{2nd Appointmen}

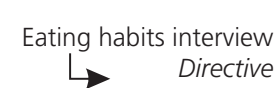

Survey regarding the individual's

eating habits

Sleep tracking

\section{3rd Appointment}

Registry of hedonic food sensations of appetite, satiation, satiety and hunger control

(Figure 3)
Describing and dimensioning the pain caused by the loss

Description of pain

Scales to dimension pain**
Characterization of berevement and the cause of death of the beloved one

Directive interview

Three-day dietary records***

Figure 1. Methodological procedures to guide the investigative approach regarding the eating habits of bereaved individuals*

Note: *Figure 1 shows a diagrammatic indication using arrows for the application of the forms that compose Chart 1 and Figure 2 and other methods (R24h, QFA, Hedonic Sensitivity Scales, Dietary records). The dotted arrows signify a preferred sequence to approach the information and the continuous arrows highlight the focus of the approach. The whole proposal is based on previous care with the emotional preservation of the bereaved. Inferences to the words death and bereavement already trigger affective-emotional reactions in the bereaved person, thus, the principle of logic contributes, above all, to the care instituted to the approach of bereavement, while respecting the boundaries that may be established by the bereaved individuals themselves; ${ }^{* *}$ Scales for measuring the dimension of pain. For bereavement, the combination of two scales is indicated - the Visual Numerical Scale (VNS) and Behavioral Scale (BS) are suggested. The VNS consists in quantifying the pain intensity through a numerical classification ranging from zero (no pain) to ten points (maximum pain, of unbearable intensity). The BS has a differential because it is based on the evaluation of occupational activities and care due to the reminder of pain. The VNS quantifies the intensity of pain and the BS shows whether pain compromises the individual's occupations and eating, hygiene and health habits. The result of the pain intensity associated to the BS provides to collaborate data to the analysis of the influence of pain regarding the loss of a beloved one in food ingestion and eating practices; ${ }^{* * *}$ Optional, depending on the willingness of the individual and the stage of bereavement to perform the dietary records. Source: Elaborated by the authors. 


\section{First appointment}

Given the distinction of this survey and the differences in the individuals' emotional regulation profiles, the scheduling of the first interview is an essential channel of dialogueprogramming. Despite this caution, one may note the need to postpone the first interview if the bereaved person is too apprehensive regarding the survey, for recalling the circumstance of the death of the beloved one and exposing painful moments of bereavement.

By postponing talking about the death of the beloved one, the interviewer may allow some time for the bereaved to develop an identification with the interviewer. When the bereaved feels supported, without even realizing it, they begin to spontaneously remember and narrate the period of bereavement. It is up to the interviewer to ensure that information of interest is obtained while preserving the well-being of these individuals. This requires constructive interpersonal postures [3] and emotional balance to deal with emotional reactions or tensions, which may arise concurrently to those reported.

In order to alleviate the occurrence of strong emotional reactions and to avoid interferences resulting from structured eating habits-related directive questioning, the approach to eating habits should be initiated by applying the non-directive interview.

\section{Non-directive dietary habits interview, recorded in audio}

The course of this interview allows the bereaved to freely express their perceptions about feeding during their bereavement period. Through these narratives, individual eating attitudes and settled behaviors in affective relationships (with the deceased and other family members) are explored, whose information will aid in understanding how the bereaved is relating to food and with the hedonic and symbolic feelings of the food.

Chart 1 contemplates the guiding contents for this approach, without intending to be taken as a model form.

Conceiving that these guiding contents should only suggest the theme [25], subjects not spontaneously mentioned should be included in the dialogue, with open questions so that the bereaved can narrate them. Explaining:

Chart 1. Approach of eating attitudes in bereavement from the perspective of the non-directive eating habits interview.

Guiding questions for approaching eating attitudes in bereavement

PART I - Knowing the bereaved individual's attitude towards food before the death of the beloved one

Tell me about your eating habits, before bereavement (if not stated during the spontaneous report, ask):

Tell me about the sensations, feelings and emotions linked to the act of eating.

(thirst, hunger, appetite, satiation and satiety, feelings and emotions that one can feel when eating). Tell me about the sensations, feelings and emotions experienced in a meal environment. Tell me what, in your perception, would be important for me to know.

PART II - Knowledge of the bereaved individual's attitude towards food after the death of the beloved one Tell me about your relation with food, after the death of your beloved one.

Tell me about your attitude toward food after the death of your beloved one. (explain the meaning of "attitude").

Directives: changes in diet; changes in attitudes linked to the act of eating; description of the sensations, feelings and emotions experienced in a meal environment; absence of the beloved one at mealtime imposing any kind of difficulties; identification of food or cuisine that symbolize the memory of the deceased; identification of changes from the beginning of bereavement until the present moment.

Tell me, today, of your attitudes toward food. What observations could you describe to me?

What is your opinion about eating in bereavement? 
tell me how the family has reacted at mealtimes the intention is to identify whether individual reactions to the loss of the loved one have had any repercussions on the family's dietary habits and whether the presence of other family members has imposed a eating attitude to bereaved individuals.

The interviewer should remain in active listening mode without the interference of continuous annotation [3], and without inferring in induction errors or by manifesting their opinions [25], avoiding anything that might influence the speech of the bereaved. It is recommended to conduct an audio test of the bereaved person's voice to make you more comfortable with the recording, allowing you to hear the result of this procedure; at which point the interviewer reinforces the advantages of audio and ethical principles for the recorded information. Recording the interview allows for advantages in the sense of respecting the original expressions and the presence of paralinguistic signals - restricting itself to the capture of reactions (pauses or silences) and of emotions (crying) that are sustained concomitantly with the speeches.

Considering that the professional practice in food orientation does not take place in a single meeting, the recording will benefit for re-readings, for a better understanding of the speeches and expressions, facilitating the decision making for interventions. Assuming that the experience of bereaved individuals is very relevant to understanding bereavement and their eating behavior, this requires an intensive analysis of interviews, audio recording in the context of this protocol has positive implications - different perspectives which allow for specific demands for acceptance and conduct. From this procedure, we have the potential of the recorded speech that allows the professional to deepen in the trajectory of understanding the experience between bereaved individuals and their eating habits.
Bereavement is an inevitable process of assimilating to loss [26]. When listening to bereaved people, words such as sadness, discouragement, pain, commonly appear under different contexts, combined with adverbs that modify or intensify their meanings. [...] "After my son's death [pause]. I feel a lot of pain [pause]. And a lot of sadness... I do not feel hungry". Starting from the words in evidence, the meaning is derived from this structuring basis. In a preliminary analysis, this example indicates: the type of bereavement; refers to the stressor event - the son's death; exposes an intensity of pain and sorrow - with the adverb "very"; brings reservations to the child's death through the use of the word "after"; reinforces the absence of hunger with the adverb of negation "no"; and identifies emotional signals through the use of pauses.

The exemplified narrative associated with non-verbal information contains a set of factors that can mediate their relation to food, evidencing the need for deepening in these issues. It is emphasized that the task of interpreting speech requires knowledge of appropriate techniques to highlight important theoretical findings and conclusions $[15,16]$ in association with the abstracted results of eatingrelated inquiries.

\section{Describing and dimensioning the pain of losing a beloved one}

The pain of losing the beloved one (selfreported) can interfere with the individual's eating habits. This is a psychic pain that causes physical impressions through discomfort [27], nourishing the feeling of malaise, depleting the energy and the willingness of doing anything, including from this perspective the refusal to eat and/or the loss of interest in food. In bereaved individuals, it is necessary to investigate if there is a report of absence of hunger, slow chewing, prolonged fasting and lack of concern with what one eats or drinks [7] - behavioral conditions 
that are strongly associated with reports of intense and uninterrupted pain.

Measuring the intensity of pain increases the perception of pain caused by a loss in the daily eating habits of the bereaved. In order to make its intensity (which is subjective) a comparative measure, we suggest the combined application of one-dimensional scales of measurement of the pain dimension [28] by introducing them with a brief statement about the pain caused by the loss of the beloved one. Explaining: each person expresses himself differently regarding pain. Before choosing one of the following alternatives, reflect a little on these questions - did the death of the beloved one caused you pain? How do you scale this pain? Being aware of your thoughts and actions, among the options for each scale, choose the one that most represents the dimension of pain, regarding your bereavement. Pondering the equivalence between the intensity of this variable and the lack of motivation of the bereaved to eat, or when binge eating, we seek to understand the interference of the pain of losing a beloved one regarding food. Despite the lower occurrence of cases of binge eating, the food can be a refuge to the pain caused by a loss [7], indicating the need for this investigation. It is expected that when compared to less intense forms of pain, eating and consumption to be close to what it was before the death of the beloved one. The application of the pain dimension scales [28] is useful in this investigation and does not exceed the time of five minutes, taking into account the access to the instructions and familiarization of the bereaved with each scale.

\section{Bereaved individuals' characterization}

It includes the personal identification, socio-economic and family conditions (family and social support, resources to face the loss) and health (care, presence of pathologies, appearance or development of diseases, selfreported diseases and use of medication) of the bereaved, as well as other questions about death and bereavement. The bereaved is approached to discuss the moment he was informed about the beloved one's death; the bond he had with the deceased; the personal information of the deceased; of the cause of death; participation in the funeral and burial; of living and the experience of bereavement; and other losses prior to this. Given the fact that it is a directive inquiry about bereavement, it is indicated in Figure 1 the application of these questions in the thirty minutes before the end of the first appointment. It is assumed that during the non-directive interview the interviewer had the chance to establish a bond of trust and empathy with the bereaved, conditions considered as facilitators to approach death and bereavement.

The time of bereavement is a parameter that allows for, in association with other data, an analysis of the evolution of the coping with the loss [29]. There are bereaved individuals who count the years, the months, and even the days of the beloved one's death, as accurately as if he/her said: My loss is felt every day. Although the time of bereavement has relevance for the behavioral analysis, it is in the representation of its meanings that true intentions are revealed. Eating habits are dependent on the conditions of assimilation of death and loss - how does the bereaved respond to loss and absences? How does this process interfere with eating? Bereaved people have very different attitudes even though they had the same time span to recover. Based on the cognitive style to process emotions, each one experiences its coping mechanisms [22,30]. However, the affective bond regarding the deceased (son, spouse, parents etc.) and the cause of death are conditions that are aggravating the response to the adaptive behavior pattern of the bereaved, having direct reflexes to his/her diet.

\section{Second appointment}

In the second interview (60 minutes), the goal is to establish the pattern of food intake and the time of sleep of the bereaved. 


\section{Eating habits survey}

The combined application of the 24-hour recall (R24h) methods with the Food Frequency Questionnaire (FFQ) is useful for estimating energy and nutrient intakes, portion sizes and volumes, meal intervals and consumption frequencies of eating $[2,8,31]$ of reconstructed practices [14]. To establish the amount of food that the bereaved consumes, some precautions should be taken by the interviewer. Serving portions of food is not the same as eating, but it is one of the indicators that helps in clarifying the relation between the bereaved to food, for evidencing the food (solid or liquid) that is accepted and tasted concomitant to the process of bereavement. It is important to inquire about food leftovers on the dish [8] because of the tendency of the bereaved individual to manifest absence of hunger [7].

Due to emotional stress, the bereaved may have limitations in remembering all foods that have been eaten. The interviewer must return to the bereaved what has been reported for each food in the previous 24 hours, giving him the opportunity to adjust food types, quantities and/or combinations without any kind of influence. During the application of the R24h method it is necessary to distinguish the food which have been ingested from those mentioned by bringing back memories from the deceased. Bereaved individuals tend to express more about the favorite food and culinary of the deceased - something that expresses a lot but does not necessarily match the person's eating habits. The technical skill of the interviewer is critical in distinguishing the foods that are actually being eaten.

Some bereaved individuals tend to distance themselves from the consumption of foods that trigger diverse memories, meanings, and sensations; while others need to preserve eating as one of the ways to express homage to the beloved one. It is evident that the first tastings are always confused as representations of the beloved one, accentuating the longing and the feeling of loss; but it is through eating that the sensory attributes of each food or cuisine are again appreciated together with memories [32]. The bereaved one's arguments for the acceptance or rejection and even exclusion (temporary or definitive) of these foods should be known.

\section{Sleep tracking}

Sleep deprivation or even regular cases of insomnia are frequent symptoms caused by the stress related to the death of the beloved one [7] and these conditions interfere in the hunger control and satiety systems. Shortened sleep increases the ghrelin to leptin ratio, leading to an increasing appetite and hunger [33]; however, bereaved individuals do not respond in this way to their eating habits, inappetence occurs [7], which means that the bereaved person's dietary habits that are influenced by their psyche.

Sleeping time needs to be investigated. The interviewer must inquire about the time of the time the bereaved person goes to bed, the time he feels more tiredness, the time they wake up in the morning, the amount of hours of sleep, and if they are using any kind of sleeping medication - types, posology and times of ingestion.

\section{Third appointment}

The third appointment aims to obtain a record of hedonic sensations of satiety and hunger control, as well as any dietary records.

\section{Record of hedonic sensations of satiety and hunger control}

Despite the existence of instruments which are legitimized to obtain such records, such 
as the weekly food journal [9] and visual analogue scales for hunger and satiety measurement [34-36], completing these forms requires the participation of trained and motivated individuals regarding the recording of the requested information [9], for one week, uninterrupted.
In the case of bereaved individuals, the option for instruments with less printed material, with a good, appropriated layout and easy to be filled, can favor the adhesion of these individuals to the registration of pre and postprandial sensations, since they are sensitized to the

\section{HUNGER, APPETITE SATIATION AND SATIETY FORM}

For each meal you had in the day of record, please choose the alternative that best

reflects your sensation.*

Meal: — Time (start): _— Time (finish)

Where was the meal taken:

Are you hungry right now?

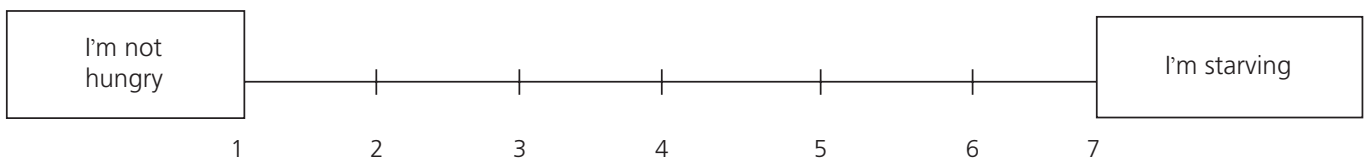

Do you feel satiated (full) even before eating?

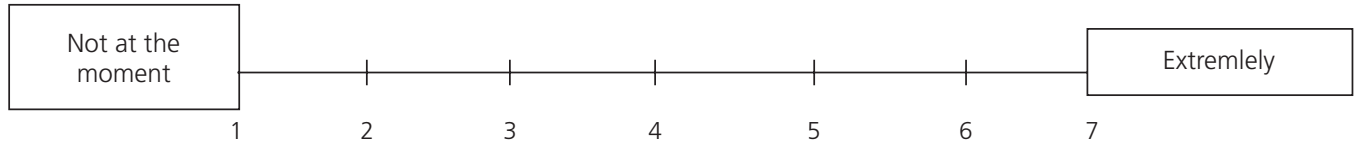

How is your appetite (a desire to eat some kind of food in special), at the moment?

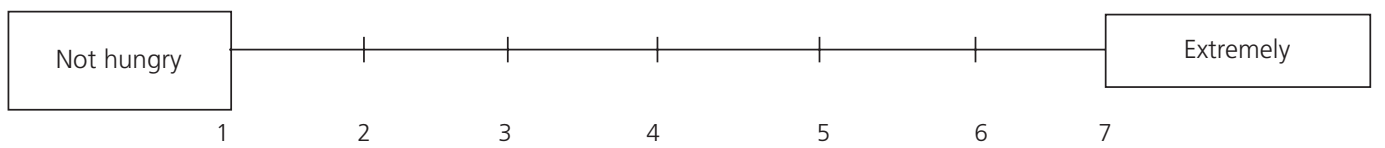

Would you like to have a longer interval between the previous meal and this one?

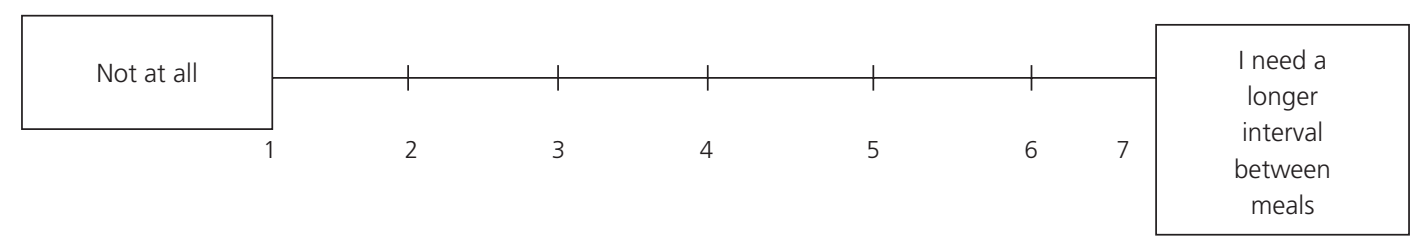

To what extent does the meal (or sandwich, or snack) look appetizing?

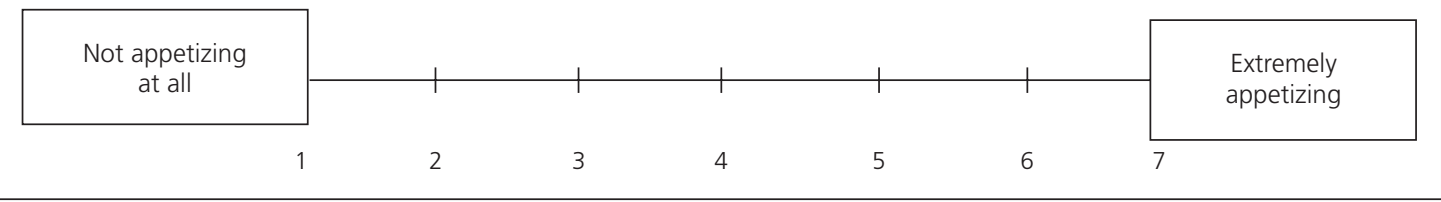

Figure 2. Registration form of the hedonic sensations of hunger, appetite, satiation and satiety.

Note: " 1 =extremely; 2 =moderately; $3=$ slightly; $4=$ feeling of indifference; $5=$ slightly; $6=$ moderately; $7=$ =xtremely.

Source: form adapted from Visual Analog Scale (Feuz et al. [9]; Flint et al. [36]). 
importance of this activity. When facing a recent bereavement, it is clear that the individual's motivation for filling out food forms does not exist. The anhedonia present in bereavement [7] has unfavorable implications for doing extensive activities and for filling forms regarding their eating habits. The request for registration of the hedonic sensations on three consecutive days, instead of one week, should be considered for bereaved individuals (Figure 1), by favoring the completion of the forms and the commitment to return the information to the interviewer. It is suggested to register on consecutive days to avoid forgetfulness that could lead to their withdrawal from this study.

Simplified registration forms, such as the example (Figure 2), are more suitable options for recording the hedonistic sensations of bereaved individuals.

After the first year of bereavement, preferably, the record of the hedonic sensations when eating should be done one or two weeks before the date (day and month) of the death or birth of the beloved one; or close to other special dates of events celebrated in family. These dates can revive absences of the beloved one, and can affect the bereavement by causing alterations to sleep patterns, mood and eating habits. This record, in critical periods of remembering the deceased, intends to identify and to understand the eating sensations that are established in those periods; which, even with the passing of time, still influence some individuals.

\section{Dietary records}

In this protocol (Figure 1), the threeday dietary record $[2,8]$ is an optional method. However, due to the demand regarding their notes [8], bereaved individuals are not always willing to perform this activity.

The dietary record should be performed on alternate days and covering a weekend day
[2]. Conditions that also restrict its use with individuals under high emotional stress, to infer in the possibility of forgetfulness. Thus, indicators of the applicability of this instrument to the investigation of bereaved individuals (Figure 3) are presented, based on these considerations: time of bereavement [29]; stages of reaction to the loss of the beloved one [37]; distinction of loss; and personality pattern.

Having verified the possibility of applying the dietary record and having consent from the bereaved, its use is indicated in the periods ( 1 to 2 weeks) prior to the date of death or birth of the deceased, inserting the questions that are appropriate to this investigation. The purpose of this stage, in this investigation protocol, is to provide more individualized assistance related to eating during critical periods of events that fuel the feelings of longing and absence of the beloved one.

\section{CONCLUSION}

Regarding the limitations of the study, it is important to observe that when using the protocol, it is necessary to consider the need for adaptations according to the regional customs related to bereavement and feeding. It is hoped that the application of the protocol in a greater number of tests can broaden the understanding of the psychic mechanisms of bereavement which substantiate changes in eating habits and as a consequence, new discussions will consolidate the most appropriate tools to conduct food research in bereavement.

It should be emphasized that although this protocol contains guidelines that guide the process of professional care or research; for both situations, different kinds of adaptations are planned, depending on the context of the professional care and the purposes of the research. 


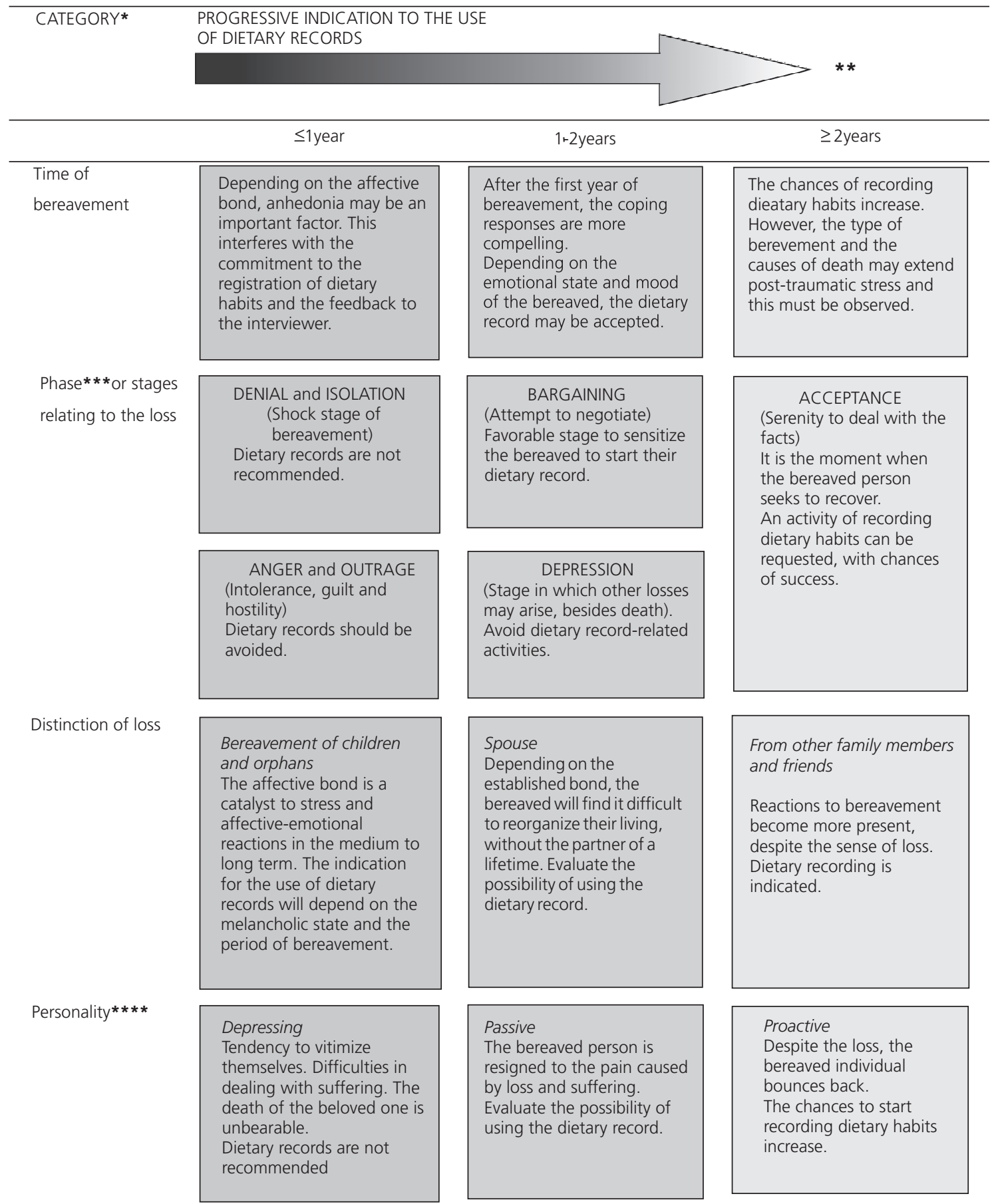

Figure 3.Indication of dietary habits record with bereaved individuals.

Note: "The categories in the first column of Figure 3 are represented by four variables to be observed, and for each of these variables, the possibilities of success in applying the dietary habits record are described horizontally as indicated by the arrow. The conditions signaled in lighter gray, and closer to the arrowhead, are more favorable circumstances for the instrumentation of the bereaved individual with their dietary habits record; "* The intensity of color, as represented the arrow and the columns, indicates differences in the chances of obtaining the dietary habits record. The further away from the black color, the greater the chances of success with the activity of recording dietary habits; ${ }^{* * *}$ Stages of bereavement as proposed by psychiatrist and thanatologist Kübler-Ross [37] - it should be noted that the temporariness of each stage varies from individual to individual, due to personal singularities and the context of loss, which reinforces the need for diagnostic dexterity; ${ }^{* * * *}$ The individual's personality interferes in the profile of emotional regulation [22] - in the presence of personalities (proactive and passive) that favor the bereaved to resignify the pain caused by the loss of the beloved one and the meaning of life, the use of the dietary habits record can be applied, depending on the instrumentalization of method and the sensitization of these to this activity.

Source: Elaborated by the authors. 


\section{OLLABORATORS}

MTFS CAMPOS participated in the design and analysis of this study, drafted the manuscript and critically reviewed it for important intellectual content. MCG PELUZIO co-advised the study, participated in the review and approval of the final version of the manuscript. RMA ARAÚJO, guiding professor for this study, contributed substantially to its concept, to the critical review of the manuscript and approved the version to be published.

\section{R E F E R E N C E}

1. Rodrigues EM, Soares FPTP, Boog MCF. Resgate do conceito de aconselhamento no con texto do atendimento nutricional. Rev Nutr. 2005;18(1):119-28. http://dx.doi.org/10.1590/S14 15-52732005000100011

2. Willett WC. Nutritional epidemiology. 3th ed. Oxford: Oxford University Press; 2013.

3. Feldman C, Miranda ML. Construindo a relação de ajuda. 14a ed. Belo Horizonte: Crescer; 2004.

4. Ferreira VS. Artes e manhas da entrevista compreensiva. Saúde Soc. 2014;23(3):979-92. http:// dx.doi.org/10.1590/S0104-12902014000300 020

5. Santos EM, Sales CA. Familiares enlutados: compreensão fenomenológica existencial de suas vivências. Texto Contexto Enferm. 2011;20(Esp):214-22. http://dx.doi.org/10.1590/s0 104-07072011000500027

6. Freitas JL, Michel LHF. A maior dor do mundo: o luto materno em uma perspectiva fenomenológica. Psicol Estud. 2014;19(2):273-83. http://dx.doi. org/10.1590/1413-737222324010

7. Campos MTFS. A influência do luto no comportamento alimentar e suas implicações nas condutas nutricionais. Ciênc Saúde Coletiva. 2013;18(9):2761-71. http://dx.doi.org/10.1590/ S1413-81232013000900032

8. Fisberg RM, Martini LA, Slater B. Métodos de inquéritos alimentares. In: Fisberg RM, Slater B, Marchioni DML, Martini LA. Inquéritos alimentares: métodos e bases científicas. Barueri: Manole; 2005. p.1-29.

9. Feuz AS, Assis MAA, Passos MMCF. Métodos de inquéritos alimentares com abordagens do comportamento alimentar. In: Fisberg RM, Slater B, Marchioni DML, Martini LA. Inquéritos alimentares: métodos e bases científicas. Barueri: Manole; 2005. p.32-52.
10. Rossato SL, Fuchs SC. Handling random errors and biases in methods used for shortterm dietary assessment. Rev Saúde Pública. 2014;48(5):845-50. http://dx.doi.org/10.1590/S00 34-8910.2014048005154

11. Cambraia RPB. Aspectos psicobiológicos do comportamento alimentar. Rev Nutr. 2004;17(2):217-25. http://dx.doi.org/10.1590/S1415-527320040002 00008

12. Douglas $C R$. Controle da ingestão alimentar. In: Douglas CR, organizador. Tratado de fisiologia aplicada à nutrição. São Paulo: Robe Editorial; 2002. p.473-84

13. Halpern ZSC, Rodrigues MDB, Costa RF. Determinantes fisiológicos do controle do peso e do apetite. Rev Psiq Clin. 2004;31(4):150-3. http:// dx.doi.org/10.1590/S0101-60832004000400002

14. Poulain J-P, Proença RPC. Reflexões metodológicas para o estudo das práticas alimentares. Rev Nutr. 2003;16(4):365-86. http://dx.doi.org/10.1590/S141 5-52732003000400001

15. Minayo MCS. O desafio do conhecimento: pesquisa qualitativa em saúde. 14a ed. São Paulo: Hucitec; 2014.

16. Bardin L. Análise de conteúdo. São Paulo: Edições 70; 2011.

17. Bevan MT. A method of phenomenological interviewing. Qual Health Res. 2014;24(1):136-44. http://dx.doi.org/10.1177/1049732313519710

18. Lamont M, Swidler A. Methodological pluralism and the possibilities and limits of interviewing. Qual Sociol. 2014;37(2):153-71. http://dx.doi.org/10. 1007/s11133-014-9274-z

19. Freitas JL. Luto e fenomenologia: uma proposta compreensiva. Rev Abordagem Gestalt. 2013;19(1):97-105.

20. Fisberg RM, Marchioni DML, Colucci ACA. Avaliação do consumo alimentar e da ingestão de nutrientes na prática clínica. Arq Bras Endocrinol Metab. 2009;53(5):617-24. http://dx.doi.org/10.15 90/S0004-27302009000500014

21. Poulain J-P, Proença RPC, Diez-Garcia RW. Diagnóstico das práticas e comportamentos alimentares: aspectos metodológicos. In: Diez-Garcia RW, Cervato-Mancuso AM, organizadores. Nutrição e metabolismo: mudanças alimentares e educação nutricional. Rio de Janeiro: Guanabara Koogan; 2011. p.149-63.

22. Chesney SA, Gordon NS. Profiles of emotion regulation: Understanding regulatory patterns and the implications for posttraumatic stress. Cogn Emot. 2017;31(3):598-606. http://dx.doi.org/10. 1080/02699931.2015.1126555 
23. Bertamoni T, Ebert G, Dornelles VG. Estudo correlacional sobre diferentes perfis de estratégias de coping de acordo com os traços de personalidade. Aletheia. 2013 [acesso 2017 out 16];42:92-105. Disponível em: http://pepsic.bv salud.org/scielo.php?script=sci_arttext\&pid=S14 13-03942013000300009\&lng=pt

24. Gross JJ, John OP. Individual differences in two emotion regulation processes: Implications for affect, relationships, and well-being. J Pers Soc Psychol. 2003; 85(2):348-62. http://dx.doi.org/10. $1037 / 0022-3514.85 .2 .348$

25. Hoffmann MV, Oliveira ICS. Entrevista não diretiva: uma possibilidade de abordagem em grupo. Rev Bras Enferm. 2009;62(6):923-7. http://dx.doi. org/10.1590/S0034-71672009000600021

26. Basso LA, Wainer R. Luto e perdas repentinas: contribuições da terapia cognitivo-comportamental. Rev Bras Ter Cogn. 2011 [acesso 2017 abr 22];7(1):35-43. Disponível em: http:// pepsic.bvsalud.org/scielo.php?script=sci_arttext\& pid=S1808-56872011000100007\&lng=pt\&tlng = pt

27. Pimenta SO. A morte de um filho para uma mãe: luto, melancolia e identificação [tese]. Curitiba: Universidade Federal do Paraná; 2014.

28. Freitas CC, Vieira PR, Torres GVB, Pereira CRA. Avaliação da dor com o uso das escalas unidimensionais. Rev Dor. 2009;10(1):56-62.

29. Parkes CM. Luto: estudos sobre a perda na vida adulta. São Paulo: Summus; 1998.

30. Bonanno GA, Burton CL. Regulatory flexibility an individual differences perspective on coping and emotion regulation. Perspect Psychol Sci. 2013;8(6):591-612. http://dx.doi.org/10.11 77/17 45691613504116
31. Moreira SLN, Silva JA, Andrade KC. Instrumentos de inquérito dietético utilizados na avaliação do consumo alimentar em pacientes de uma clínica escola de nutrição: comparação entre dois métodos. Rev Bras Ciênc Saúde. 2008;18(6):21-6.

32. Campos MTFS, Coelho AIM. A culinária que simboliza a memória viva do ente querido e estratégias úteis. In: Campos MTFS, Coelho AIM. Alimentação saudável na terceira idade: estratégias úteis. 3a ed. Viçosa (MG): Editora UFV; 2013. p.43-52.

33. Crispim CA, Zalcman I, Dáttilo M, Padilha HG, Tufik S, Mello MT. Relação entre sono e obesidade: uma revisão da literatura. Arq Bras Endocrinol Metab. 2007;51(7):1041-9. http://dx.doi.org/10.1590/S0 004-27302007000700004

34. Haber GB, Heaton KW, Murphy D, Burroughs LF. Depletion and disruption of dietary fibre: Effects on satiety, plasma-glucose, and serum-insulin. Lancet. 1977;2(8040):679-82.

35. Holt SHA, Miller JB. Increased insulin responses to ingested foods are associated with lessened satiety. Appetite. 1995;24(1):43-54. http://dx.doi. org/10.1016/S0195-6663(95)80005-0

36. Flint $A$, Raben $A$, Blundell JE, Astrup A. Reproducibility, power and validity of visual analogue scales in assessment of appetite sensations in single test meal studies. Int J Obes. 2000;24(1):38-48.

37. Kübler-Ross E. Sobre a morte e o morrer. 10a ed. São Paulo: Martins Fontes; 2017.

Received: November 16, 2017

Final version: February 21, 2018 Approved: April 25, 2018 